\title{
The Study of Professional Nursing Practice Models (PNPM) Application on Islamic Nursing Care
}

\author{
$1^{\text {st }} \mathrm{D}$ Mustikaningsih \\ Program Studi Pendidikan Profesi Ners \\ STIKes Aisyiyah Bandung \\ Indonesia \\ aning_klw@ymail.com
}

\author{
$2^{\text {nd }}$ T Setiawati \\ Program Studi Pendidikan Profesi Ners \\ STIKes Aisyiyah Bandung \\ Indonesia
}

\author{
$3^{\text {rd }}$ SU Rifaatul Fitri \\ Program Studi Pendidikan Profesi Ners \\ STIKes Aisyiyah Bandung \\ Indonesia
}

\begin{abstract}
Background. The application of Professional Nursing Practice Models ( PNPM ) on Islamic nursing care among patients requires the methods and systems such as human resource planning including the training of sharia care among nurses, facilities and equipment for the patients worship, as well as the implementation of handover based on sharia standard operating procedures and documentation of Islamic spiritual nursing care. Purpose. Theobjective of this study was to identify the application of professional nursing practice models (PNPM). Method. The method used in the whole of this study wasphenomenological qualitative byinterviewing the divisional head of nursing, the sectional head of nursing, the team leader, the shift leader and 71 nurses the head of the nursing section, the team leader, the head of the shift and 71 nurses in RumahSakit Al-Islam Bandung. Data collection techniques with in-depth interviews, observations, and documentation studies, supported by focus group discussions and logbooks were conducted. The data were analyzed by quantitative and qualitative descriptive using reduction, display and reflection drawing verification data. Results. The results showed that there were four themes namely the organizing form, the number and qualifications of human resources, the implementation of nursing care methods and the completeness of facilities and infrastructure. Conclusion. It can be concluded that the application of Professional Nursing Practice Models ( PNPM) has been done based on Islamic nursing care in Al- Islam Bandung Hospital. It was suggested to make the guidelines for the sharia professional nursing practice (PNPM) model.
\end{abstract}

\section{Keywords-Islamic Nursing Care, PNPM}

\section{INTRODUCTION}

The quality of Islamic nursing services is determined by the management of nursing care that is the management of Nursing Human Resources. In nursing care management, it is known as the professional nursing practice model. There are three components of nursing care management, one of which is the organizing system [1]. The application of professional nursing practice model in
Islamic Hospital is very varied based on the analysis of the hospital's situation, such as team and modular method. Team nursing method is a nursing practical model which is conducted by a group of nurses to a group of patients in one shift while modular model is a nursing practical model comprehensively which is an application combination from team and primary model called primary nursing modification.

Samsualam research results concluded that the application of services with sharia principles gives satisfaction to the patients with service characteristics namely Rabbaniyyah, Akhlaqiyyah, Waqi'iyah, and Insaniyyah. In this study, there was an increase of the patients' satisfication and from the multiple regression test results, it is known that the patient's satisfaction is influenced by Rabbaniyyah, Akhlaqiyyah, Waqi'iyah and Insaniyyah [2].

Islam nursing services applied in Professional Nursing Practice Model (PNPM) requires a method, and a specific system such as organizing that the hospitals establish the structure of the spiritual division. Spiritual division working unit is responsible for the islamic maintenance of patients' and the hospital's staff. The existence of spiritual division is responsible for fostering and encouraging the patients and the hospital staffs to be cautious to Allah based on Islam religion [3]. The normative foundation "QS. Ali Imran: 104 which describes about the task of amar ma'ruf nahi munkar. The nursing human resource is a unit in a staff recruiting process, an increase of competency and career development using Islamic principles [4]. All of guidances and policies get recommendations from sharia committees, then the number and qualifications of Islamic nursing human resource must have professional nurses, namely nurses who are qualified as under graduate nursing and have staff competencies with sharia principles at least 5 people in one room and its facilities. The facilities and equipments must be sufficient namely facility management such as planning, 
procurement, and maintenance according to the patients' spiritual needs, the patient and visitor worship facility and the proportional worship needs [5].

It can be concluded from the observation results in the form of the nursing human resource characteristic data that there were some elements that did not meet the requirements in the implementation of PNPM in Islamic nursing care. The results of interviews with the head of the nursing division and section was that the Islamic nursing care model has been applied in the form of PNPM using a modular method but its application has never been assessed yet based on sharia standards so it has been known that it is whether appropriate with the sharia standards or not. Some components still overlap with the normative standards in general modular methods, so the way of PNPM application model is needed to be assessed.

The formulation of the problems in this study was about how the PNPM is applied in Islamic nursing care in order to analyze PNPM application in Islamic nursing care of Al-Islam Bandung Hospital.

\section{METHOD}

This study used phenomenological quantitative and qualitative method [6]. The subjects of this study were the head of nursing division, the head of nursing section, team leader, the head of shift and 71 nurses in 10 inpatient rooms namely Darussalam 3, Darussalam 3A, Darussalam 4, Darussalam 5, ICU, HCU, Perinatology, peurperal, NurusSholihat and Raudhah rooms. Data collection was conducted by interview and observation. The validity test of quantitative and qualitative data was done. The study was conducted by in- depth interviews with head of nursing division, the head of nursing section, the head of rooms, team leader, the head of shift. Seventy-one nurses were observed for professional nursing care and also nursing documentation in the inpatient rooms of RumahSakit $\mathrm{Al}$ Islam Bandung. The process and analysis of quantitative data used frequency descriptive technique. The stages of data analysis were conducted, they are,: (a) the managing, (b) reading and memorizing, (c) describing, (d) classifying, (e ) interpreting, and (f) visualizing data. ${ }^{6}$ This study has accepted ethical clearance from the research ethical committee of STIKes' Aisyiyah Bandung and Al-Islam Bandung Hospital.

III. RESULTS.

A. Univariate Analysis

1. Characteristics of Respondents

\begin{tabular}{|c|c|c|}
\hline Characteristics & Frequency & Percentage (\%) \\
\hline $\begin{array}{c}\text { Gender } \\
\text { Man } \\
\text { Girl } \\
\text { Total }\end{array}$ & $\begin{array}{l}23 \\
48 \\
71\end{array}$ & $\begin{array}{c}32.4 \\
67.6 \\
100.0\end{array}$ \\
\hline $\begin{array}{c}\text { Age } \\
21-24 \text { years old } \\
25-29 \text { years old } \\
>30 \text { years old } \\
\text { Total } \\
\end{array}$ & $\begin{array}{c}8 \\
26 \\
37 \\
71 \\
\end{array}$ & $\begin{array}{c}11.3 \\
36.6 \\
52.1 \\
100.0 \\
\end{array}$ \\
\hline $\begin{array}{c}\text { Education } \\
\text { D-3 Nursing } \\
\text { S-1 Nursing } \\
\text { S-1 Nursing Profession (Ners) } \\
\text { Total }\end{array}$ & $\begin{array}{c}56 \\
6 \\
9 \\
71\end{array}$ & $\begin{array}{c}78.9 \\
8.5 \\
12.7 \\
100.0\end{array}$ \\
\hline $\begin{array}{c}\text { How long have you worked } \\
<1 \text { year } \\
1-5 \text { years } \\
6-10 \text { years } \\
>10 \text { years } \\
\text { Total } \\
\end{array}$ & $\begin{array}{c}1 \\
18 \\
27 \\
25 \\
71\end{array}$ & $\begin{array}{c}1,4 \\
25.4 \\
38.0 \\
35.2 \\
100.0\end{array}$ \\
\hline $\begin{array}{c}\text { Employee Status } \\
\text { Honorary } \\
\text { Permanent employee } \\
\text { Contract } \\
\text { Total }\end{array}$ & $\begin{array}{c}8 \\
59 \\
4 \\
71\end{array}$ & $\begin{array}{c}11.3 \\
83.1 \\
5.6 \\
100.0\end{array}$ \\
\hline
\end{tabular}

Table I shows that in the distribution of respondents by sex in the inpatientroom of RumahSakitAl-Islam Bandung, the most respondents were women as 48 people $(67.6 \%)$. The most respondents based on age category wasaged $>30$ years as many as 37 people $(52.1 \%)$. Most of respondent based on educational background were nursing D-3 graduates as many as 56 people (78.9\%). Most of respondents based on the the length of working were 6-10 years as many as 27 people $(38.0 \%)$ and most of respondents based on employee's status were 59 permanent employees $(83.1 \%)$.

2. The study analysis of the Professional Nursing Practice Models Implementation in Islamic Nursing Services

Based on the results of the analysis of interviews, the researchers have made the coding, categorization and themes. There are 32 categorizations, 15 sub themes and 4 themes. Those themes are a).the form of 
organization $b$ ). the numbers and qualifications of human resources c). the implementation of nursing care methods d). facilities and infrastructure. The themes from the analysis of the results of the interview are described as a whole below: a). The organization form of Islamic nursing service b). The numbers and qualifications of human resources, c). The Implementation of Islamic Nursing Care TABLE II. FREQUENCY DISTRIBUTION OF RESPONDENTS BASED metho which includes model form, handover, case reflection discussion, medicine sentralization, supervision, patient admission, integrated discharged planning, intergrated nursing documentation and computerized Islamic spiritual documentation, d) the completeness of sharia standard service facilities and infrastructure.

3. The Observation Results of the handover process AL-ISLAM BANDUNG

\begin{tabular}{|c|c|c|c|}
\hline Sub Variable & Category & Frequency & Percentage $(\%)$ \\
\hline \multirow{4}{*}{$\begin{array}{l}\text { Islamic nursing handover } \\
\text { procedure }\end{array}$} & Good & 69 & $97.2 \%$ \\
\hline & Enough & 2 & $2.8 \%$ \\
\hline & Low & 0 & $0 \%$ \\
\hline & & 71 & $100 \%$ \\
\hline \multirow{4}{*}{$\begin{array}{l}\text { The contents of the Islamic } \\
\text { nursing shift handover }\end{array}$} & Good & 65 & $91.5 \%$ \\
\hline & Enough & 6 & $8.5 \%$ \\
\hline & Low & 0 & $0 \%$ \\
\hline & & 71 & $100 \%$ \\
\hline \multirow{4}{*}{$\begin{array}{c}\text { The method of Islamic nursing } \\
\text { shift handover }\end{array}$} & Good & 20 & $28.2 \%$ \\
\hline & Enough & 48 & $67.6 \%$ \\
\hline & Low & 3 & $4.2 \%$ \\
\hline & & 71 & $100 \%$ \\
\hline \multicolumn{4}{|l|}{ Total } \\
\hline \multirow{4}{*}{$\begin{array}{l}\text { Islamic nursing shift handover } \\
\text { communication }\end{array}$} & Good & 58 & $81.7 \%$ \\
\hline & Enough & 13 & $18.3 \%$ \\
\hline & Low & 0 & $0 \%$ \\
\hline & & 71 & 100.0 \\
\hline
\end{tabular}

Based on the results of table II, the handover process which was done by the nurse for hand over procedure was in the good category (97.2\%), the handover contents was in the good category $(91.5 \%)$, the handover method was in the enough

category $(67.6 \%)$ and the

handover communication was in the good category $(81.7 \%)$.

4. Observation Results of Islamic Spiritual Nursing Care Documentation

TABLE III. FREQUENCY DISTRIBUTION OF COMPUTERIZED ISLAMIC SPIRITUAL NURSING CARE DOCUMENTATION

\begin{tabular}{|c|c|c|c|c|c|c|}
\hline \multirow{4}{*}{ Variable } & \multicolumn{6}{|c|}{ Darussalam Room 3, Darussalam 4 and Darussalam 5} \\
\hline & \multicolumn{6}{|c|}{ Results } \\
\hline & \multicolumn{2}{|c|}{ Good } & \multicolumn{2}{|c|}{ Enough } & \multicolumn{2}{|c|}{ Less } \\
\hline & $\mathrm{N}$ & $\%$ & $\mathrm{~N}$ & $\%$ & $\mathrm{~N}$ & $\%$ \\
\hline Spiritual nursing assessment & 53 & $93 \%$ & 34 & $59.6 \%$ & 13 & $7.15 \%$ \\
\hline $\begin{array}{c}\text { Spiritual nursing } \\
\text { Diagnosis }\end{array}$ & 0 & $0 \%$ & 0 & $0 \%$ & 100 & $100 \%$ \\
\hline Spiritual nursing intervention & 0 & $0 \%$ & 0 & $0 \%$ & 100 & $100 \%$ \\
\hline $\begin{array}{l}\text { Spiritual nursing } \\
\text { Implementation }\end{array}$ & 0 & $0 \%$ & 38 & $66.7 \%$ & 24 & $42.1 \%$ \\
\hline $\begin{array}{c}\text { Spiritual nursing } \\
\text { Evaluation }\end{array}$ & 0 & $0 \%$ & 0 & $0 \%$ & 100 & $100 \%$ \\
\hline
\end{tabular}

According to table III, in the quantitative frequency distribution of computer-based Islamic spiritual nursing care on the patient's medical record in Darussalam 3, 4 and 5 rooms, the documentation of the assessment of Islamic spiritual nursing was in the good category as many as $93 \%$, in the enough category as many as $59 \%, 6 \%$ ) and in the less category as many as $7.15 \%$. The documentation of Islamic spiritual nursing diagnosis was in the less category as many as $100 \%$. There documentation of Islamic spiritual nursing intervention was in the less category as many as $100 \%$. The documentation of Islamic spiritual nursing implementation was in the enough category as many as $66.7 \%$ and was in the less category as many as $42.1 \%$, The documentation of Islamic spiritual nursing evaluation was in the less category as many as $100 \%$.

\section{4. DISCUSSION}

The results of competency Islamic nursing service on the nurses in giving Islamic nursing service was in the case of giving worship guidances such as thaharah, guiding prayers by lying down and sitting, guiding wudlu by doing tayamum, guiding prayers and tadzkirah activities [7]. This competence is called as the basic competence of Islamic nurses while the horizontal line is coordinated with the spriritual committee and the mosque manager whose the staff carries out it is called Asatid. Asatid visits the patient rooms every day and intervenes for spiritual issues in a fiqh manner.

The study analyses of number and qualification of human resource showed that there is at least SR2 with the control range of nurses in treating the patient in the room 
as many as one nurse: 7 patients and the team leader is in charge of seven nurses every shift with Islamic nursing care method implementation including the nurses do the handover in the inpatients room (nurse station) per team led by the room leader consisting of three stages [8]. The first stage is preparation stage before starting a meeting started by praying together and reading an Al-Quran and asmaulhusna. The second stage is handover implementation stage: the room leader or a person in charge opens the meeting started by greeting before doing handover then the nurses inform the progress of patients' condition generally and the patients' worship especially while being hospitalized; the termination stage is finished by praying together and greeting [9].

The study analysis of Islamic spiritual nursing care documentation showed that spiritual nursing study includes Islamic aspect, the usage of veil for the women patients, the patients' ability to purify herself, prayer implementation, the obstacles not to do prayer and a belief about the diseases [10]. The sheet of spiritual nursing diagnosis documentation lists the diagnosis of spiritual nursing consisting of spiritual distress and spiritual distress risk by filling in the checklist [11]. Qualitatively, there still was a diagnosis that has been studied in the available form such as the lack of knowledge about the prayer implementation, the disturbances of worship practice, the readiness of worship practical progress, the risk of worship practical disturbances and the readiness of spiritual welfare progress [12]. Interventional documentation is appropriate with the nursing diagnosis, implementation and evaluation recorded in the implementation and integrated development note[13].

The analysis of the facility and infrastructure completeness support the Islamic nursing services for the patient's family such as the small musholla (the special room for prayer) for women in each floor providing sajadah (kind of special rug for prayer), mukena (special woman clothes when doing prayer), and Al-Quran while for the men, it is suggested to payer in the mosque. The worship tools for the patients are provided in each room such as sajadah, mukena, veil, sarong, Al quran and special place of the dust for doing tayamum [14].

\section{CONCLUSIONS}

Based on the results, it can be concluded that the implementation of Professional Nursing Practice Model (PNPM) in the inpatient room has described about Islamic nursing care that used modular method by involving spiritual committee and mosque management by involving asatid, a staff who is always in the room every day. The implementation of Islamic shift handover has been conducted by doing Islamic nursing shift handover communication in each inpatient room of Al-Islam Bandung Hospital. The study's result showed that the Islamic shift handover implementation was in the good category as $81.7 \%$, the procedure of nursing shift handover was also in the good category as $97.2 \%$, the content of Islamic nursing shift in doing handover bedside method was in enough category as $67.6 \%$. Computerized nursing care documentation includes nursing care based on national accreditation standard and Islamic spiritual documentation.

There were many limitations in this study including policies and rules regarding Islamic nursing care that have not been made in the form of sharia PNPM guidelines. In order to achieve more satisfying results, further study regarding the development of sharia standard professional nursing practice models is needed.

\section{ACKNOWLEDGMENT}

We would like to thank to all who have assisted in the implementation process until the completion of this research, to Sekolah Tinggi Ilmu Kesehatan 'Aisyiyah Bandung as the funder of this research. We also thank the Al-Islam Hospital West Bandung District for providing opportunities and assisting us in data collection. Finally, we thank all parties and colleagues at STIKes 'Aisyiyah Bandung for their support and motivation.

\section{REFERENCES}

[1] A. W. Doreen, Spirituality in nursing practice: The basics and beyond. Springer Publishing Company, 2016.

[2] V. H. Samsualam and A. S. , Werna Nontji, "Model of Spiritual Nursing Care Based Islamic Perspective in Islamic Hospital of Ibnu Sina Makassar," Int. J. Sci. Basic Appl. Res., vol. 24, no. 4, 2015.

[3] Mukisi, Pedoman Standar Pelayanan Minimal Rumah Sakit Syariah. Jakarta: Mukisi, 2017.

[4] A. S. Musa, "Spiritual care intervention and spiritual wellbeing: Jordanian Muslim nurses' perspectives," J. Holist. Nurs., vol. 35, no. 1, pp. 53-61, 2017.

[5] F. J. P. del Pino, "Nurses and Muslim patients: two perspectives on Islamic culture in the hospital," Procedia-Social Behav. Sci. vol. 237, pp. 1131-1137, 2017.

[6] S. Tarsito, "Metode Penelitian Kuantitatif, Kualitatif dan R\&D," Alf. Bandung, 2017.

[7] Inggriane Puspita Dewi, Qur'anic Therapy. Bandung: Sekolah Tinggi Ilmu Kesehatan 'Aisyiyah Bandung, 2016.

[8] N. Nursalam, Manajemen keperawatan: Aplikasi dalam praktek keperawatan profesional. 2016.

[9] M. Zaccagnini and J. M. Pechacek, The doctor of nursing practice essentials: A new model for advanced practice nursing. Jones \& Bartlett Learning, 2019.

[10] M. Asadzandi, "Sound Heart, Spiritual Health from the perspective of Islam," J. Relig. Theol., vol. 3, no. 1, pp. 10-16, 2019.

[11] N. A. Boucher, E. A. Siddiqui, and H. G. Koenig, "Supporting Muslim patients during advanced illness," Perm. J., vol. 21, 2017.

[12] C. Atkinson, "Islamic values and nursing practice in Kuwait," J. Holist. Nurs., vol. 33, no. 3, pp. 195-204, 2015.

[13] A. I. Padela and D. Zaidi, "The Islamic tradition and health inequities: A preliminary conceptual model based on a systematic literature review of Muslim health-care disparities," Avicenna J. Med., vol. 8, no. 1, p. 1, 2018.

[14] N. Dehghan-Nayeri, F. Ghaffari, and M. Shali, "Exploring Iranian nurses' experiences of missed nursing care: a qualitative study: a threat to patient and nurses' health," Med. J. Islam. Repub. Iran, vol. 29, p. 276, 2015. 